\title{
Lav fosterdødsrisiko etter termin i Norge
}

\author{
Risikoen for fosterdød etter termin er lav her i landet. Mye tyder på at skadevirkningene ved å sette i gang \\ fødselen i uke 41 er større enn en eventuell gevinst, muligens med unntak av hos kvinner over 35 år.
}

Fredrik Frøen, avdelingsdirektør ved Folkehelseinstituttet, har i landsdekkende medier foreslått at fødsler som ikke er kommet i gang innen svangerskapsuke 41 gerskapsuke $37 \mathrm{i}$ den siste perioden var halvert i forhold til perioden 1967-86. Fosterdødsrisikoen i Norge er blant de laveste i verden, og det er nå nesten ingen økning

\section{«Fosterdødsrisikoen i Norge er blant de laveste i verden, og det er nå nesten ingen økning i risikoen for fosterdød etter termin.»}

skal induseres. Hensikten er å forhindre fosterdød. Forslaget har vakt harme hos mange klinikere og frykt blant gravide kvinner. Blant annet er det opprettet en Facebook-gruppe som kaller seg «Ikke la gravide gå mer enn syv dager over termin! REDD LIV!». Gruppen har nå over 36500 medlemmer.

\section{Fosterdødsrisiko}

Før man foreslår generelle tiltak for å redusere forekomsten av fosterdød etter termin bør man vite hva den faktiske risikoen er - og om denne risikoen er høyere etter termin enn ved termin. For å beregne gestasjonsspesifikk fosterdødsrate må nevneren $\mathrm{i}$ analysene være kvinner som ennå ikke har født.

Vi har gjort slike analyser blant alle som var gravide i perioden 1967-2006, med data fra Medisinsk fødselsregister (1). Svangerskapslengden er beregnet på grunnlag av dato for siste menstruasjon for årene inntil 1999 og ut fra ultralydmål i svangerskapsuke 17-19 fra og med 1999. I de tilfellene der kvinnen ikke har vært til terminbestemmende ultralydundersøkelse, er svangerskapslengden beregnet ut fra første dag av siste menstruasjon. Risikoen for fosterdød per 1000 pågående svangerskap blant kvinner i alderen 20-24 år var 0,9 i svangerskapsuke $40,1,3$ i uke $41,2,0$ i uke 42 og 3,7 i uke 43. Blant kvinner over 40 år var fosterdødsraten i de samme svangerskapsukene henholdsvis 2,4, 3,6, 8,4 og 24,8 . Det er få tilfeller av fosterdød etter uke 42 og derfor statistisk usikkerhet knyttet til dette estimatet.

Vi studerte også endringen i risiko for fosterdød fra 1967 og sammenliknet periodene 1967-86 og 1987-2006 (1). Her fant vi at forekomsten av fosterdød etter svan- i risikoen for fosterdød etter termin. I den grad fosterdødsrisikoen øker etter termin i dag, ser dette ut til å gjelde utelukkende for kvinner som er 35 år eller eldre.

\section{Nye tiltak for å forebygge fosterdød?}

Fredrik Frøen hevdet i helseprogrammet Puls på NRK1 at sju av 11 dødfødsler på overtid kunne vært unngått ved hjelp av fødselsinduksjon i svangerskapsuke 41 (2). Et generelt råd om igangsetting av fødsler i svangerskapsuke 41 vil antakelig bidra til en vesentlig økning av antall induksjoner, ettersom $11 \%$ av alle fødsler finner sted etter uke 41. Induksjon er ikke komplikasjonsfritt for den enkelte kvinne, og det krever betydelige ressurser ved fødeavdelingene. Mange studier viser at induksjon av fødsel øker risikoen for keisersnitt eller andre operative forløsninger, særlig hos førstegangsfødende (3). Et keisersnitt er heller ikke uten risiko, verken i det aktuelle eller i påfølgende svangerskap.

Spørsmålet er om man får ytterligere nedgang i fosterdødsraten ved å indusere fødsel hos alle kvinner i uke 41 - og om en eventuell gevinst er større enn skadevirkningene. Det finnes så langt vi vet ingen studier som har tilstrekkelig statistisk styrke til at man kan konkludere med at induksjon er å foretrekke fremfor å la den fødende gå post termin (4-7).

\section{Bør klinisk praksis endres?}

Endring av fødselsrutiner krever store ressurser for poliklinikker og fødeavdelinger. Før man foretar en slik omstilling, trengs det gode studier med tilstrekkelig styrke til at utfallet kan vurderes. Debatt om klinisk praksis er alltid viktig, men det er ikke sikkert at en slik debatt skal startes i riksdekkende medier.
Endring av praksis må være basert på kunnskap om at endringen vil redde liv. Våre tall tyder på at fosterdødsrisikoen etter termin er svært lav i Norge, særlig blant kvinner under 35 år. Det er lite trolig at induksjon av fødselen hos alle kvinner som er i svangerskapsuke 41 vil være god klinisk praksis. Reduksjonen i fosterdødsrisko ved og etter termin som har funnet sted siden 1967, skyldes sannsynligvis at bedre svangerskaps- og fødselsomsorg allerede er implementert.

\section{Camilla Haavaldsen}

marit.camilla.haavaldsen@ahus.no

Aahshi Sarfraz

Kvinneklinikken

Akershus universitetssykehus

1478 Lørenskog

og

Institutt for klinisk medisin

Akershus universitetssykehus

Universitetet i Oslo

\section{Anne Eskild}

Kvinneklinikken

Akershus universitetssykehus og

Divisjon for psykisk helse

Folkehelseinstituttet

Oppgitte interessekonflikter: Ingen

Litteratur

1. Haavaldsen C, Sarfraz AA, Samuelsen SO et al. The impact of maternal age on fetal death: does length of gestation matter? Am J Obstet Gynecol 2010; e-publisert 26.8

2. Husøy S. - Folkehelsa skremmer opp gravide. www.nrk.no/programmer/tv/puls/1.7111180 (16.9.2010).

3. Menticoglou SM, Hall PF. Routine induction of labour at 41 weeks gestation: nonsensus consensus. BJOG 2002; 109: 485-91.

4. Heimstad R, Romundstad PR, Salvesen KA Induction of labour for post-term pregnancy and risk estimates for intrauterine and perinatal death. Acta Obstet Gynecol Scand 2008; 87: 247-9.

5. Augensen K, Bergsjo P. Eikeland T. Randomised comparison of early versus late induction of labour in post-term pregnancy. BMJ 1987; 294: 1192-5.

6. Wennerholm U-B, Hagberg H, Brorsson B et al. Induction of labor versus expectant management for post-date pregnancy: is there sufficient evidence for a change in clinical practice? Acta Obstet Gynecol Scand 2009; 88: 6-17.

7. Gulmezoglu AM, Crowther CA, Middleton P. Induction of labour for improving birth outcomes for women at or beyond term. Cochrane Database Syst Rev 2006; nr. 4.

Manuskriptet ble mottatt 21.5. 2010 og godkjent 16.10. 2010. Medisinsk redaktør Anne Kveim Lie. 